\title{
A Literature Review of Women Empowerment and Development in Zimbabwe: A look at New Insights and Perspectives
}

\author{
Dr Faitira Manuere \\ Department of Entrepreneurship and Business Management \\ Chinhoyi University of Technology- Zimbabwe \\ Neria Phiri \\ Department of Entrepreneurship and Business Management \\ Chinhoyi University of Technology- Zimbabwe
}

Received: July 31, 2018 Accepted: Oct. 9, 2018 Online published: Oct. 23, 2018

doi:10.5296/jpag.v8i4.13818 URL: https://doi.org/10.5296/jpag.v8i4.13818

\begin{abstract}
The concept of "Women empowerment" has received much attention from researchers, government and captains of industry. There are several meanings attached to the concept of women empowerment. This literature review explores the origin of the term women empowerment as it is related to gender and equality. This literature review looks at four power perspectives that are used to explain the increasing need for women empowerment today. The related concepts of power, agency, resources and achievements are used to explain and describe the problems associated with women empowerment globally. The theoretical underpinnings of this literature review are important for policy-makers and government the world over. Finally, the models that can be adopted to empower women, socially, economically and politically are identified and explained.
\end{abstract}

Keywords: women empowerment, power perspectives, gender equality, captains of industry, government and policy-makers.

\section{The Definition of Empowerment}

The beginning of the concept of empowerment can be traced back to the works of Paulo Freire (1921-1997), a Brazilian scholar, who championed the concept of "the Pedagogy of the Oppressed". Freire (1974) argues that every society consists of two forces, the oppressor and 
the oppressed. According to Freire (1974) the duty of a teacher is to make students aware of the social injustice in society so that they can create the means to liberate themselves. The concept of empowerment takes its root from other sources, such feminism, Freudian psychology, theology, the Black Power empowerment, and Ganddhism (Simon, 1994; Cornwall an Brock, 2005). According to Whitmore (1998:13) empowerment is:

... an interactive process through which people experience personal and social change, enabling them to take action to achieve influence over the organisations and institutions which affect their lives and the communities in which they live.

Empowerment is a process in which people acquire social, economic and political power to liberate themselves from injustices in society (Wallerstein, 1992). Empowerment is a situation in which people, organisations and communities acquire the needed control over the problems that affect them (Rappaport 1987; Zimmerman, 1995). The concept of empowerment cannot be understood just as a single definition. The concept of empowerment must be understood in relation to the specific needs of the people who are yearning for empowerment (Kabeer, 2005). The concept of women empowerment is now explained.

\section{Women Empowerment}

Women empowerment is a situation in which women are given the opportunity to participate fully in social, political and economic spheres of life, (Sushama, 1998). Empowering woman entail creating an enabling environment in which women are allowed to implement government programmes and organisational policies that affect their lives (Chattopadhyay, 2005; Aspy and Sandhu, 1999; Patricia et al, 2003). Women empowerment is the situation in which women move from the state of being oppressed to the state in which both the oppressor and the oppressed are equal, socially, politically and economically (Chattopadhyay 2005). The concept of empowerment can be understood better when contextualised to social, educational, economic, political and psychological empowerment of women. The social empowerment of women addresses areas of gender inequities that exist between men and women in society (Srivstav, 2001; Mira Shivaa, 2001).

Women empowerment simply means increasing educational opportunities of women so that they are able to make meaningful decisions about themselves and their families ( Pathak 2003). The economic empowerment of women refers to the process of according women the power to become "bread winners" to be self- reliant to generate income from projects and fight poverty (Elliot 2008). The political empowerment of women is the process of advancing women's political interests ( Pam Rajput, 2001; Tiwari, 2001).

The psychological empowerment of women refers to the process in which woman increase their motivation, self -interests and morale to become more involved in national programmes, such as education, politics, health matters, agricultural issues and developmental programmes (Pam Rajput, 2001; Tiwari, 2001). 


\section{Gender Equality and Women Empowerment}

Gender equality is defined as the process of "levelling the playing field for both men and women so that all sexes" are able to develop their talents in a given geographical environment (UNICEF, 2008). Gender equality, as another form of women empowerment, means according women equality of opportunity and removing obstacles that hinder women from participating fully in commerce, education, politics and culture (Backhans, 2007). Studies have shown that gender equality is addressed by giving women more access to land, credit market and labour opportunities (Morrison, et al, 2007). Several studies have revealed that gender equality correlates highly with economic growth. According to Kishor (1997) there is a positive relationship between gender inequality and low per capita income. It is also argued that there is an inverse relationship between gender inequality and low government expenditure on education (Morris et al, 2007). Dollar and Gatti (1999) argue that cases of gender inequality are more numerous in the poorer countries of Africa, Latin America and Asia. According to Rahman (2013) gender inequality is a product of the power relationships that exist between women and men in society. Rowland (1997) argues that every human society has a way of rewarding one sex with more power to the extent that the sex that has no power over the control of resources becomes the oppressed lot. According to Luke (1974) the concept of power in women empowerment helps researchers, academics and policy makers to examine the underlying social and cultural structures that define gender relations. Table 1, shows the power relations perspectives that influence women empowerment in society.

Table 1. Power Relations Perspectives

\begin{tabular}{|c|c|c|}
\hline Type of power relation & $\begin{array}{l}\text { An 'agency' approach to } \\
\text { empowerment }\end{array}$ & $\begin{array}{l}\text { Changing structures for } \\
\text { empowerment }\end{array}$ \\
\hline $\begin{array}{l}\text { 1. Power over: } \\
\text { The ability to influence } \\
\text { and coerce the actions } \\
\text { and thoughts of the } \\
\text { powerless }\end{array}$ & $\begin{array}{l}\text { Change in power relations } \\
\text { within households and } \\
\text { communities and at micro } \\
\text { level, e.g increased role in } \\
\text { decision making and } \\
\text { bargaining power. }\end{array}$ & $\begin{array}{lcr}\text { Respect } & \text { equal rights } & \text { of } \\
\text { others, } & \text { challenge } & \text { to } \\
\text { inequality } & \text { and } & \text { unfair } \\
\text { privileges. } & & \end{array}$ \\
\hline $\begin{array}{l}\text { 2. Power to: } \\
\text { The capacity to act, to } \\
\text { organise and change } \\
\text { existing hierarchies }\end{array}$ & $\begin{array}{l}\text { Increased skills, access and } \\
\text { control over income and } \\
\text { resource, and access to } \\
\text { markets and networks. }\end{array}$ & $\begin{array}{l}\text { Increased skills and resource } \\
\text { to challenge injustice, and } \\
\text { inequality faced by others. }\end{array}$ \\
\hline $\begin{array}{l}\text { 3. Power with: } \\
\text { Increased power from } \\
\text { collective action, social } \\
\text { mobilisation and alliance } \\
\text { building. }\end{array}$ & $\begin{array}{l}\text { Organisation of the less } \\
\text { powerful to enhance abilities } \\
\text { to change power relations } \\
\text { and increased participation of } \\
\text { the less powerful. }\end{array}$ & $\begin{array}{l}\text { Supportive organisation of } \\
\text { those with power to } \\
\text { challenge } \\
\text { inequality }\end{array}$ \\
\hline $\begin{array}{l}\text { 4. Power from within } \\
\text { Increased individual } \\
\text { consciousness, } \\
\text { self-dignity and } \\
\text { awareness. }\end{array}$ & $\begin{array}{l}\text { Increased confidence and } \\
\text { awareness of choices and } \\
\text { rights, widened aspirations } \\
\text { and ability to transform } \\
\text { aspirations into actions. }\end{array}$ & $\begin{array}{l}\text { Changes in attitudes and } \\
\text { stereotypes; commitment to } \\
\text { change. }\end{array}$ \\
\hline
\end{tabular}

Source: Rowlands (1997); Mayoux (2003).

Table 1 shows that the concept of 'power to' gives women access to decisions making in political, social and economic spheres of life whereas the concept of 'power within' helps 
women to acquire psychological empowerment by building self-esteem around themselves (Rowland, 1997; Mayoux, 2003). The concept of 'agency' refers to the capacity of women to be self-reliant and to have total control over their fate (Rowlands, 1997). The concept of 'structure' refers to rules, religion, gender, ethnicity, customers, and government, which motivate or hinder women from exercising significant roles in society (Rowlands, 1997; Mayoux, 2003).

\section{Women Empowerment Models}

According to Sohail (2014:8-9) women can be empowered by using the following models:

1. Institutions should be developed for providing equal resources to men and women.

2. Media and NGOs should raise awareness about women rights.

3. Policy action should be taken to reduce gender inequality.

4. Women should be provided with the education and job opportunities.

5. Women should be granted loans at lower interest rates so that they are encouraged and their skills are developed.

6. Women should have the right to own their property.

7. Women must have simple business registration procedures.

8. Male dominancy should be handled in a peaceful manner.

9. Women should have access to economic resources which leads to the economic growth.

10. For the same work equal amount of payment should be given to both men and women and the Amount should be reasonable enough so that they could spend better life.

11. There should be no discrimination in assigning work to people based on gender.

12. Both men and women should be given equal opportunities.

13. Safe working conditions should be provided to both men and women.

14. Women should be encouraged to join the fields of work which have been consideredas fields for men.

\section{Theories of Gender Equality}

Theories of gender equality are used to explain the strategies that can be utilised to empower women in society (Lipset, 1959; Rostow, 1960; Bell, 1999). Four theories of gender equality are adopted and described in detail. These theories include:

1. The classical development perspective.

2. The human development perspective.

3. The historical legacies perspective, and

4. The institutional design perspective.

\section{The Classical Development Perspective}

The theory is concerned about the empowerment of women as a function of economic development, dispensation of democracy, and the removal of social injustices that increase gender inequalities (Lipset, 1959; Rostow, 1960; Deutsch, 1964). Studies have shown that there is positive relationship between economic development and an equitable distribution of 
educational, occupational and agricultural resources (Bell, 1999; Inkeles and Smith, 1974). Several studies have shown that economic development empowers women by increasing social services to society and according women more time for child rearing and domestic work (Kenworthy and Malami, 1999; Reynolds, 1999; Rule, 1981).

\section{The Human Development Perspective}

The Beijing Declaration (Section 13) considers the empowerment of women as the sin qua non of social political and economic development in any given nation:

Women's empowerment and their full participation on the basis of equality in all spheres of society, including participation in the decision making process to power, are fundamental for the achievement of equality, development and space (Fourth World Conference on Women 4).

In the past scholars believed that women's empowerment was enhanced by encouraging financial institutions to extend lines of credit to women (Agha, 2000; Kishor, 1997; Hashemi et al 1996). Educated women have the capacity to fight against cultural practices that condemn women to oppressed position in society (Murphy and Graham, 2008). Women who are highly educated gain more access to knowledge, information and new ideas (Maslak and Singhal, 2008). Therefore the human development perspective relates women's empowerment to cultural practices of capacity building through education, training and development (Inglehart and Norris, 2003; Inglehart and Wezel, 2005).

\section{The Historical Legacies Perspective}

The historical legacies perspective considers the role of government, quasi-governmental bodies and non-governmental institutions as being critical to the empowerment of women in society. According to Najm (2013), government has a duty in developing social, political and economic programmes that empower women. Rahman and Sultana (2012) suggest that non-governmental organisations should come up with projects that give women the power to make decisions that influence positive change on their lives. Women who are allowed to participate in government managed projects have access to resources which they can use to alleviate poverty in their families (Khan and Bibi, 2011). Scholars worldwide argue that the modern state is characterised by the secularisation of the publics and this trend has enabled women to free themselves from the oppressive nature of the church and the family, to the extent that greater emphasis is now placed on rationality and individualism (Inglehart and Norris, 2003; Inglehart and Wezel, 2005; Rule, 1981; Kenworthy and Malami, 1999).

\section{The Institutional Design Perspective}

The institutional design perspective is all about the need to allow women to effectively take part in the politics of the country (Datta and Sen, 2003). Women' participation in politics is increasing at a slow pace and what is problematic is that more men than women hold more political power (The Millenium Development Goals Report, 2007:12). The global data for 1980 show that women occupied 10 percent of the world's parliaments and 4 percent of national cabinets. (The Millennium Development Goals Report, 2007:12). In 2007 women 
represented 17 percent of single and lower houses of parliament, which is a 4 percent increase from 1990 (The Millennium Development Goals Report, 2007:12). In 1993 it was shown that only six women were governmental leaders in the world. (The Millennium Development Goals Report, 2007:12). There is an inverse relationship between both the oppressive and the unequal treatment of women and the existence of political democratic institutions in the country. (McDonagh, 2002; Welzel, 2003). Research has shown that there is a positive relationship between the existence of strong democratic institutions at national level and women empowerment (Inglehart and Norris, 2003; Inglehart and Wezel, 2005).

\section{Conclusion}

The aim of the paper was to describe the four power perspectives that are used to explain the increasing need for women empowerment today. To that end the concept of women empowerment was analyzed and explained in detail. It was noted that there are several meanings attached to the concept of women empowerment. In order to provide the needed conceptual background to the paper the concepts of power, agency, resources and achievements were used to explain the problems associated with women empowerment globally. Four theories of gender equality were also used to explain the significance of women empowerment .The theories used were, the classical development perspective, the human development perspective, the historical legacies perspective, and the institutional design perspective. The future plans of every nation should focus on articulating women empowerment issues. The long term developmental strategy of a country is incomplete without giving adequate thought to this sector and obtaining adequate information about them before making policy decisions. Women empowerment is not the same as giving women a good education or creating more employment opportunities for them. Women need to understand the rationale behind gender equality and women empowerment. In a nutshell women empowerment is the liberation of the mind from economic, political, and social injustices in society.

\section{References}

Agha, S. (2000). The Determinants of infant mortality in Pakistan. Social Science and Medicine, 51(4), 199-208. https://doi.org/10.1016/S0277-9536(99)00460-8

Aspy, C. B., \& Sandhu, D. S. (1999). Empowering women for equity: A counseling approach. American Counseling Association, Alexandria, VA. 22304

Backhams, M. C. (2007). Does increased gender equality lead to convergence of health outcomes for men and women?A study of Swedish Municipalities. Swedish National Institute of Public Health. Social Science and Medicine, May; 64(9), 1892-903.

Bell, D. (1999). The Coming of the Post-Industrial Society: A Venture in Social Forecasting. New York: Basic Books.

Chattopadhyay, A. (2005). Women and entrepreneurship. Yojana, a Monthly Journal of Ministry of Information and Broadcasting, 5(1), 123-156. 


\section{Macrothink}

Journal of Public Administration and Governance

ISSN 2161-7104

2018, Vol. 8, No. 4

Cornwall, A., \& Brock, K. (2005). Beyond Buzzwords: Poverty Reduction Participation and Empowerment in Development Policy. UNRISD 10.

Data, P., \& Sen, P. (2003). Women in Panchayats. Kolkata India. Dasgupta and Company Private Ltd.

Deutsch, K. (1964). Social Mobilization and Political Development. American Political Science Review, 55, 493-514. https://doi.org/10.2307/1952679

Elliott, C. M. (2008). Global empowerment of women: Responses to globalization and politicized religions. Routledge, New York.

Freire, P. (1974). Pedagogy of the Oppressed .New York. Herder and Herder.

Hashemi, S., Schuler, M.., \& Riley, A. (1996). Rural Credit Programs and Women' Empowerment in Bangladesh. World Development, 24(4), 635-653. https://doi.org/10.1016/0305-750X(95)00159-A

Inglehart, R., \& Norris, P. (2003). Rising Tide: Gender Equality and Cultural Change Around the World. Cambridge. Cambridge University Press. https://doi.org/10.1017/CBO9780511550362

Inglehart, R., \& Welzel, C. (2005). Modernisation, Cultural Change and Democracy: The human Development sequence. Cambridge. Cambridge University Press. https://doi.org/10.1017/CBO9780511790881

Kabeer, N. (2005). Gender equality and Women's empowerment: A critical analysis of the third Millennium Development Goal. Gender and Development, 13(1), 13-36. https://doi.org/10.1080/13552070512331332273

Kenworthy, L., \& Malami, M. (1999). Gender Inequality in Political Representation: A Worldwide Comparative Analysis: Social Forces, 78(3), 235-268. https://doi.org/10.1093/sf/78.1.235

Khan, A., \& Bibi, Z. (2011). Women's Socio-Economic Empowerment through Participatory approach. Pakistan Economic and Social Review, 49(1), 133-148.

Kishor, S. (1997). Empowerment of women in Egypt and Link to the Survival and Health of their infants. Paper presented at the Seminar on Female Empowerment and Demographic Process- 20-24 April, Lund.

Lipset, M. (1959). Some Social Requisites of Democracy: Economic Development and Political Legitimacy. American Political Science Review, 53, 69-105. https://doi.org/10.2307/1951731

Maslak, M. A., \& Singhal, G. (2008). The Identity of Educated Women in India: Confluence or Divergence. Gender and Education, 20(5), 481-493. https://doi.org/10.1080/09540250701829961 


\section{Macrothink}

Journal of Public Administration and Governance ISSN 2161-7104 2018, Vol. 8, No. 4

Mayoux, L. (2003). From Marginalisation to Empowerment: Towards a New Approach in Small Enterprises Development. Paper presented at the SDC Empowerment and Income Division Workshop on Small Enterprises Development and Empowerment, Centre Gerzeusee, Switzerland, 9-10 January.

McDonagh, E. (2002). Political Citizenship and Democratisation: The Gender Paradox. American Political Science Review, 96(10), 535-52. https://doi.org/10.1017/S000305540200031X

Morrison, A., \& Biehl, L. eds. (2007). Too Close to Home: Domestic Violence in Latin America. Washington, D.C.: Inter-American Development Bank.

Murphy-Graham, E. (2008). Opening the Black Box: Women's Empowerment and Innovative Secondary Education in Honduras. Gender and Education, 20(1), 31-50. https://doi.org/10.1080/09540250701650623

Najm, M. (2013). The Role of Development Institutions in the empowerment of Palestinian women. The Islamic University Journal of Education and Psychology Studies, 21(3), $329-276$.

Pathak, K. N., \& Tomar, J. S. (2012). Skill-Upgradation in five year plans. Yojana, August 2012, Ministry of Information and Broadcasting, New Delhi

Patricia, S. E. D., \& Mulvaney, B. M. (2003). Women, power., \& ethnicity - Working toward reciprocal empowerment. The Haworth Press, New York, London, Oxford

Rahman, S. (2013). Women's Employment in Bangladesh Agriculture: Composition, Determinants and Scope. J,. Rural Stud, 16, 497-507. https://doi.org/10.1016/S0743-0167(00)00006-1

Rahman, S., \& Sultana, N. (2012). Empowerment of Women for social Development. Journal of Arts, science and Commerce, 3(1), 50-59.

Rajput, P. (2001). Women's political participation in India: An agenda for empowerment. In Promilla Kapur (ed.), Empowering the Indian Women,New Delhi, Ministry of Information and Broadcasting, Government of India.

Rappaport, J. (1987). Terms of empowerment/examples of prevention: Toward a theory for community Psychology. Journal of Psychology, 15(2), 121-148.

Reynolds, A. (1999). Women in the Legislatures and Executives of the World: Knocking at the Highest Glass Ceiling. World Politics, 51, 547-72. https://doi.org/10.1017/S0043887100009254

Rowlands, J. (1997). Questioning Empowerment: Working with Women in Honduras. Oxford, UK: Oxfam. https://doi.org/10.3362/9780855988364

Rowstow, W. (1960). The Stages of Economic Growth. Cambridge: Cambridge University Press. 
Rule, W. (1981). Women's Underrepresentation and Electoral System. Political Science and Politics, 27(16), 689-692.

Shiva, M. (2001). Health care in last 50 years and women's empowerment. In Promilla Kapur (ed.), Empowering the Indian Women. Publications Division, Ministry of Information and Broadcasting, Government of In New Delhi.

Simon, B. L. (1994). The Empowerment Tradition in America Social Work: History. New York: Columbia University Press.

Sohail, M. (2014). Women empowerment and economic development: An exploratory study in Pakistan. Journal of Business Studies Quarterly, 5(4), 210-219.

Srivastava, R. S. (2001). Women empowerment: Some critical issue. In Abha Avasti and A.K. Srivastava (eds.),Modernity,Feminism and Women Empowerment, Rawat Publications, New Delhi.

Sushama, S. (1998). Women and Empowerment- Approach and Strategies, Discovery Publishing House, Delhi.

The Millennium Development Goals Report, 2007.

Tiwari, R. S. (2001). Feminism and globalization versus Indian women empowerment. In Abha Avasti and A.K. Srivastava (eds.), Modernity, Feminism and Women's Empowerment, Rawat Publication, New Delhi.

UNICEF (2008, May 12). UNICEF “Gender equality”.

Wallerstein, N. (1992). Powerlessness, empowerment and health: Implication for Health promotion programs. American Journal of Health Promotion, 6(3), 197-205. https://doi.org/10.4278/0890-1171-6.3.197

Wezel, C. (2003). Effective democracy, Mass Culture., \& the Quality of Elites. The Human Development Perspective. International Journal of Comparative Sociology, 4(3), 269-98.

Whitemore, E. (1988). Participation, Empowerment and Welfare. Canadian Review of Social Policy, 22(6), 51-60.

Zimmerman, M. A. (1995). Psychological empowerment: Issues and illustrations. American Journal of Community Psychology, 25(5), 581-599. https://doi.org/10.1007/BF02506983

\section{Copyright Disclaimer}

Copyright for this article is retained by the author(s), with first publication rights granted to the journal.

This is an open-access article distributed under the terms and conditions of the Creative Commons Attribution license (http://creativecommons.org/licenses/by/4.0/). 